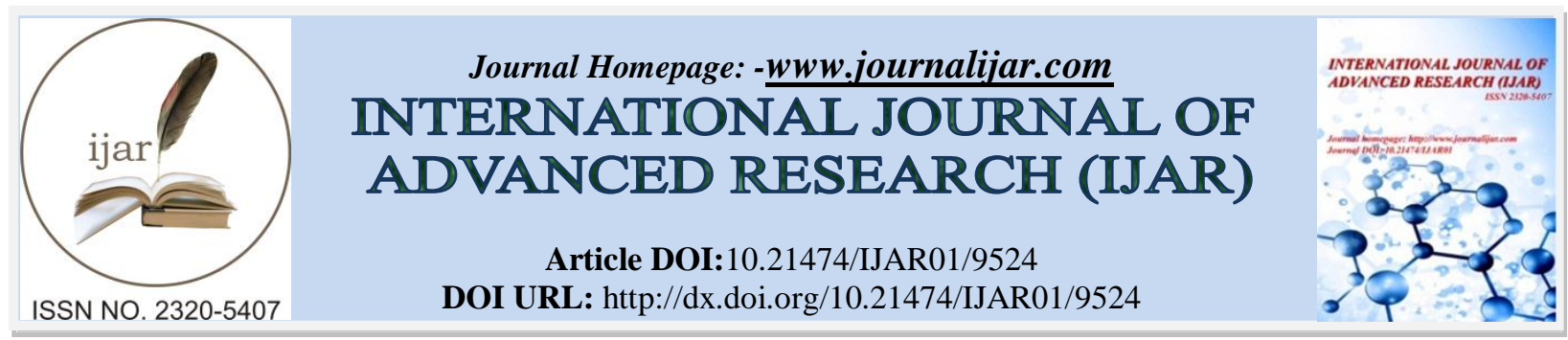

RESEARCH ARTICLE

\title{
RESPONSES TO CADMIUM- INDUCED OXIDATIVE STRESS IN MARINE MACROALGA ULVA LINZA.
}

Salwa A Abdel-Latif ${ }^{1}$, Nadia H Noaman², Eman M Fakhry² And Suzan I Ahmed ${ }^{1}$.

1. Department of Biological \& Geological Sciences, Faculty of Education,Alexandria University, Egypt.

2. Department of Botany \& Microbiology, Faculty of Science, Alexandria University, Egypt.

\section{Manuscript Info}

Manuscript History

Received: 06 June 2019

Final Accepted: 08 July 2019

Published: August 2019

Key words:-

Ulva linza, Cd, Antioxidant enzyme,

Antioxidant activity, Gene expression.

\begin{abstract}
The activities of antioxidant enzymes and gene expression of antioxidant enzymes were determined in Ulva linza under different Cdconcentrations $\left(0,50,100,200,300,400 \mu \mathrm{MCdCl}_{2}\right)$ for 3 days. The results clearly demonstrated that Cdinduced stimulation of antioxidant activity. The Cdaccumulation in thalli increased linearly as Cdconcentration increased. The decrease in growth rate, photosynthetic efficiency and protein contents with increasing of $\mathrm{H}_{2} \mathrm{O}_{2}$ and malondialdehyde (MAD) contents in response to elevated Cdconcentrations indicates the induction of the oxidative stress. As in response to the increased oxidative stress, Cdtreatments induced the activities and transcripts of superoxide dismutase (SOD; EC 1.15.1.1), ascorbate peroxidase (APX; EC 1.11.1.11), catalase (CAT; EC 1.11.1.6) and glutathione reductase (GR; EC 1.6.4.2). In general the ascorbate pool increased by treatments with different Cdconcentrations. A steady slight decrease in glutathione content with increasing Cdconcentration was indicated. The oxidized glutathione (GSSG) content and the glutathione (GSH) /GSSG ratio were not significantly influenced by the tested $\mathrm{Cd}$ concentrations, except the concentration of $300 \mu \mathrm{M}$, which caused a $18 \%$ decline in GSSG content and the concentration of $400 \mu \mathrm{M}$ which decreased GSH/GSSG ratio by $23 \%$. The different Cdconcentrations induced a conspicuous increase in proline content of the investigated alga.
\end{abstract}

Copy Right, IJAR, 2019,. All rights reserved.

\section{Introduction:-}

The bio-concentration factor is a useful parameter to evaluate the potential of plants for accumulating metals and this value was calculated on a dry weight basis (Raskin et al., 1994). It is known that marine macroalgae can accumulate heavy metals to a large extent (Baumann et al., 2009 ; Jiang et al., 2013). It is known that algal cell walls are often porous and allow the free passage of molecules and ions in aqueous solutions (Hope and Walker, 1975). In addition, the constituents of the cell wall provide an array of ligands with a mosaic of functional groups capable of binding various metallic ions. Indeed, it has been shown that many metal binding mechanisms are involved in the biosorption process; these include ion exchange, complexation, coordination, and microprecipitation (Chen et al., 2002 ; Flores-Garnica et al., 2013). Cd is a non- essential element for growth, the plants may actively exclude or sequester such to minimize the metal toxic impact (Xia et al., 2004 ; Williams and Salt, 2009).

Corresponding Author:-Salwa A Abdel-Latif.

Address:-Department of Biological \& Geological Sciences, Faculty of Education,Alexandria 
Metal toxicity has high effect and importance to plants and other autotrophs and since these organisms are primary producers, it will consequently affect the whole ecosystem. Heavy metal toxicity emerges through non specifically bonding of metals with coordination sites of important biological molecules such as enzymes and other proteins, thereby altering normal metabolic functions and affect various physiological and biochemical processes of the cell (Sunda, 1989; Arunakumara and Xuecheng, 2008). Toxicity can also be deeply related to the production of reactive oxygen species (ROS) and the resulting unbalanced cellular redox status (Sharma and Dietz, 2009; Panda et al., 2016).Cadmium with no reported biological function (non-essential) for most living organisms except one occasion as a cofactor for carbonic anhydrase in marine diatom which catalyzes the reversible hydration of carbon dioxide (Park et al., 2008 ; Hurd et al., 2014). It seems to be more or less toxic to plants and micro-organisms (Benavides et al., 2005; Gratãoet al., 2005). Performed studies in different plant species have showed that $\mathrm{Cd}$ can intervene with several metabolic processes such as photosynthesis, respiration or nutritional status (Sandalio et al., 2001 ; Dourado et al., 2014), although the mechanisms involved in its toxicity has not been well established (Romero-Puertas et al., 2007 ; Tchounwou et al.,2014). Heavy metals such as copper, zinc, mercury, lead, cadmium, chromium, aluminium and arsenic motivate oxidative stress in plants and thereby the accumulation of oxidized macromolecules (Valko et al., 2005; Sharma and Dietz, 2009). The oxidative stress condition in plants is alleviated by increasing of antioxidant enzymes activities such as superoxide dismutase (SOD) which detoxify superoxide anions $\left(\mathrm{O}_{2}{ }^{-}{ }^{-}\right)$, catalase (CAT), ascorbate peroxidase (APX), dehydro ascorbate reductase (DHAR) and glutathione reductase (GR), which detoxify hydrogen peroxide $\left(\mathrm{H}_{2} \mathrm{O}_{2}\right)$ (Sharma and Dietz, 2009; Gill and Tuteja, 2010 ; Caverzan et al., 2016 ).

Furthermore, oxidative stress can be buffered by the production of non enzymatic water soluble antioxidant compounds such as ascorbate (AsA) and glutathione (GSH) which directly reduce reactive oxygen species (Foyer and Noctor, 2011; Takami et al., 2012 ; Caverzan et al., 2016) and/or act as substrates for antioxidant enzymes such as APX, dehydro-ascorbate reductase (DHAR) or GR. In addition, proline can be added to a group list of nonenzymatic antioxidants that is required by microbes, animals, and plants to confront the inhibitory effects of ROS (Chen and Dickman, 2005; Liang et al., 2013).Linking physiological responses to stress with their genetic bases, especially using current genomic and proteomic approaches, would definitely ameliorate our understanding of the relationship between organisms and their environment. However, although fast development of, and more expedite access to, genomic tools have enhanced a look of research for the genetic bases of a wide range of biologically related processes in a diverse array of organisms, studies on algae are still scarce (Stanley et al., 2005 ; ContrerasPorcia et al., 2011). Real-time PCR is one of the most sensitive and reliably quantitative techniques for analysis of gene expression. It is well known that the synthetic antioxidants, such as butylated hydroxyl anisol (BHA) and butylated hydroxyl toluene (BHT), are commonly used to preserve food quality mainly by prevention of oxidative induced deterioration of lipids constituent. But they contribute to some negative health side effects, according to the published literature (Santoso et al., 2004; Lobo et al., 2010). Therefore, there is a growing interest on the discovery of natural antioxidants. At present, marine algae are becoming the focus for targeting effective antioxidants towards oxidative stress in human body due to the presence of diverse natural products with unique structures possibly caused by extreme marine environment (Ryu et al., 2009; Bouhlal et al., 2011). Marine algae are considered to be a rich source of antioxidants (Devi et al., 2011; Kelman et al., 2012). Furthermore, marine algae have also been used as a source of novel functional foods with potential nutritional benefits (Santoso et al., 2004 ; Figueiredo et al., 2016), because they rich in vitamins, minerals, dietary fiber, protein, and various functional polysaccharides (Kuda et al.,2005). Antioxidant activity of marine algae is being intensively investigated due to the currently growing demand from the food and pharmaceutical industries, where there is interest in anti-aging and anticarcinogenic natural bioactive compounds (Ganesan et al., 2008; Murugan and Iyer, 2012). But the exposure of marine algae to continuously and extreme fluctuations in abiotic conditions for example, temperature, salinity, $\mathrm{pH}$, and heavy metal pollution could affect their efficiency as a source of natural antioxidant compounds. Therefore, study of abiotic stress- induced changes in this efficiency become important requirement.

In this study, the green alga Ulva linza that inhabits marine environment of Alexandria City was examined under cadmium metal stress. This was to get insight into the metal-induced prospective changes in the potential commercial uses of this alga as natural antioxidative resource for food, medicine, pharmaceutical, and cosmetic industries. Ulva linza was exposed to different elevated concentrations of $\mathrm{Cd}$. The growth rate, photosynthetic efficiency, protein content, lipid peroxidation, and $\mathrm{H}_{2} \mathrm{O}_{2}$ content were quantified as an indication of cellular damage that may be induced by exposure to $\mathrm{Cd}$. Subsequently, the regulation of proline, antioxidant enzymes and non enzymatic antioxidants were determined to evaluate their possible role in the struggle against $\mathrm{Cd}$ toxicity. Furthermore, in order to linking the physiological responses to metal stress with their genetic bases, a real time 
PCR-based assay was performed to determine the transcript abundance of antioxidant enzymes genes. Quantification the total antioxidant activity of the investigated alga was also performed.

\section{Materials And Methods:-}

Algal Collection, Seawater Sampling and Experimental Setup

Healthy thalli of U. linza were collected from about one and half meter depth of Mediterranean Sea shore of Alexandria, Abu-Qir district. Alga was transported to the laboratory in a cooler at $5-7{ }^{\circ} \mathrm{C}$. Thalli were extensively rinsed with filtered seawater. Seawater stocks were filtered through $0.2 \mathrm{~mm}$ pore size membrane filters and stored in darkness at $4{ }^{\circ} \mathrm{C}$ until used. The cleaned thalli were acclimatized to laboratory conditions by culturing in glass jars containing filtered seawater gently bubbled with air and maintained under a 12:12 h light: dark cycle, $50 \mu$ mol photons $\mathrm{m}^{-2} \mathrm{~s}^{-1}$ of white cool fluorescent lamps at $25{ }^{\circ} \mathrm{C} \pm 2$ for $24 \mathrm{~h}$. Following the acclimatization period, thalli with known weight $(10 \mathrm{~g} \mathrm{FW})$ were transferred to other glass jars containing $1 \mathrm{~L}$ of filtered seawater supplemented with $50,100,200,300$ and $400 \mu \mathrm{M}$ of $\mathrm{CdCl}_{2} \cdot \mathrm{H}_{2} \mathrm{O}$ for 3 days under the same conditions of the acclimatization period described earlier. Controls were cultivated in seawater without metal additions. There were three replicates per treatment.

\section{Determination of Bioconcentration Factor}

The bioconcentration factor $(\mathrm{BCF})$ was calculated using the equation: $\mathrm{BCF}=\mathrm{C}_{\mathbf{b}} / \mathrm{C}_{\mathbf{i}}$ where, $\mathrm{C}_{\mathrm{b}}$ is the concentration of the metal in the dry macroalgal biomass and $\mathrm{C}_{\mathbf{i}}$ is the initial concentration of the metal in the feed solution (DeForest et al., 2007). The heavy metal content in algal tissue was measured according to a modified procedure of that described by Mamboya et al.(2007) as follows: 0.1g of the oven dried algal sample was placed in conical flask with $3 \mathrm{ml}$ of $60 \%$ hydrochloric acid and $10 \mathrm{ml}$ of $70 \%$ nitric acid. The conical flask was then placed on a laboratory hot plate for digestion until the white fume evolving from the conical flask turned brown. The digest was allowed to cool and then filtered through a Whatman's filter paper. The filtrate was then made up to $25 \mathrm{ml}$ using distilled water and analysed for heavy metal concentrations using Atomic Absorption Spectrophotometer (Perkin Elmer 2380).

\section{Estimation of Daily Growth Rate}

The daily growth rate (DGR) of alga as a percentage of fresh weight increase per day was calculated according to the equation: $\mathrm{DGR}=\left[\left(\mathrm{W}_{\mathrm{t}} / \mathrm{W}_{\mathrm{o}}\right)^{1 / \mathrm{t}}{ }_{-1}\right] \times 100$ (Collênet al., 2003 ; Kumar et al., 2010). Where $\mathrm{W}_{\mathrm{t}}$ is the fresh weight at time $t, W_{0}$ is the initial fresh weight and $t$ is the time in days.

\section{Determination of Photosynthetic Efficiency}

The maximal quantum yield of PSII in the dark-adapted state is expressed as a ratio of variable to maximal chlorophyll (Chl) fluorescence (i.e. Fv/Fm) of the samples was measured by Chl fluorometer, Aqua Pen-P AP-P 100 (Photon Instruments System, Czech Republic). Before Chl fluorescence readings were taken, thalli were adapted for $15 \mathrm{~min}$ in the total darkness to complete re-oxidation of PSII electron acceptor molecules (Han et al., 2008).

\section{Determination of Protein, Proline, $\mathrm{H}_{2} \mathrm{O}_{2}$ and malondialdehyde Content}

Total protein was extracted by adding $10 \mathrm{ml}$ of $0.5 \mathrm{~N} \mathrm{NaOH}$ to about $100 \mathrm{mg}$ of the oven-dry algal material and left overnight. The extract was completed to known volume with distilled water (Rausch, 1981). The protein was assayed according to modified Lowry method that given by Hartree (1972). Proline content was determined spectrophotometrically following the ninhydrin method of Irigoyen et al.(1992). Hydrogen peroxide was measured by homogenizing the algal tissue $(50 \mathrm{mg})$ in an ice bath with $5 \mathrm{ml}$ of $0.1 \%(\mathrm{w} / \mathrm{v})$ trichloroacetic acid (TCA) (Lee \& Shin, 2003). The homogenate was centrifuged at $12,000 \mathrm{~g}$ for $15 \mathrm{~min}$. An aliquot of $0.5 \mathrm{ml}$ of the plant extract was added to $0.5 \mathrm{ml}$ of $10 \mathrm{mM}$-potassium phosphate buffer $(\mathrm{pH} 7)$ and $1 \mathrm{ml}$ of $1 \mathrm{M}$ potassium iodide The absorbance of the supernatant was measured at $390 \mathrm{~nm}$. The level of lipid peroxidation was measured according to the thiobarbituric acid (TBA) test, which determines the malondialdehyde (MDA) as the end product of the lipid peroxidation reaction (Heath and Packer, 1968).

\section{Assays of Antioxidant Enzymes Activities}

For assays of SOD, APX, CAT and GR, algal thallus samples $(0.2 \mathrm{~g} \mathrm{FW})$ were ground in a liquid nitrogen frozen potassium phosphate buffer $\left(\mathrm{K}_{2} \mathrm{HPO}_{4} 50 \mathrm{mM}\right.$, EDTA Na $\left.\mathrm{N}_{2} 1 \mathrm{mM}, \mathrm{pH} 7\right)$ using a mortar and a pestle. The homogenate was centrifuged $\left(10,000 \mathrm{~g}, 15 \mathrm{~min}, 4{ }^{\circ} \mathrm{C}\right)$ and the supernatant was used for spectrophotometric determination of enzymatic activity (Nguyen-Deroche et al., 2012). Activity of SOD was assayed by measuring the inhibition of photochemical reduction of nitro-blue tetrazolium (NBT) (Beauchamp and Fridovixh, 1971).The activity of APX was assayed according to Nakano and Asada (1981).The CAT activity was determined by consumption of $\mathrm{H}_{2} \mathrm{O}_{2}$ in 
absorbance at $240 \mathrm{~nm}$ according to method of Aebi (1984).The GR activity was assayed according to Foyer and Halliwell (1976), with minor modifications as described by Azevedo Neto et al. (2006).

\section{Determination of Ascorbate and Glutathione concentrations}

The levels of AsA and dehydroascorbate (DHA) were determined as described by Ratkevicius et al. (2003).GSH and GSSG contents were extracted and determined according to the florescence spectroscopy method of Hissin and Hilf (1976).

\section{Quantitative Real-Time PCR Detection of Gene Expression}

Total RNA was extracted using total RNA kit I Q easy TM plus plant Korea. The Thermo Scientific ${ }^{\mathrm{TM}}$ RevertAid $^{\mathrm{TM}}$ First Strand cDNA Synthesis Kit is used for synthesis of first strand cDNA from RNA templates. Expression of the SOD APX, CAT and GR genes were determined by RT PCR; Real MOD ${ }^{\mathrm{TM}}$ GH Green Real-time PCR Master Mix (2x). The relative expression levels of the target genes (SOD APX, CAT and GR) in the investigated alga treated with different concentrations of $\mathrm{Cd}$ for 3 days were determined on the basis of normalization with the constitutive gene (Actin gene) using specific primers for amplification of both target and reference genes were designed as follows: The forward and reverse primers for real-time PCR were5'TGCACGCCGAAGGACATA3' and 5'CCAAAGCCATTGTGAATCGAG3' for SOD, 5'GTTTCAGGCAGGCAGCA3' and 5'ATTCGCATTGTTCTGGGAATC3' for APX, 5'GAATACCTTGACCAAAGTGGTT3' and 5'GTAAGTGCAGTCTACGTCG3' for CAT and 5'GATTTAGGCCAGGCGGA3' and 5'TCATTTCATCTGATCATATAACAGAACCC3'forGRand5'TGTTCCCCGGAATTGCTGATAGAATGAGC3'a nd5'TTGGAAAGTGCTGAGAGATGCCAAAATGGAG3' for Actin (Wu et al., 2009). The following amplification program was used: $94^{\circ} \mathrm{C}$ for $5 \mathrm{~min}(1 \mathrm{cycle}), 94^{\circ} \mathrm{C}$ for $30 \mathrm{Sec}$., $58-62^{\circ} \mathrm{C}$ for $30 \mathrm{Sec}$ ( 40 cycles).

\section{Estimation of Antioxidant Activity}

To evaluate the antioxidant activity of investigated Ulva linza the methanolic extract of algal samples were prepared according to the modification of the method described by Han et al. (2008). The antioxidant activity of extracts was evaluated by using the stable 2,2-diphenyl-1-picryl-hydrazyl radical (DPPH) according to a modification of the method of Bandoniene et al. (2002). The free radical scavenging activity (FRSA) of the tested samples was calculated as a percentage of DPPH discoloration using the following equation proposed by Molyneaux (2004).

$$
\text { FRSA \% }=\frac{\text { AbsB-AbsS }}{\text { AbsB }} \times 100
$$

Where, Abs B is the absorbance of blank and Abs S is the absorbance of sample

\section{Statistical Analyses}

All experiments were performed in three replicates. The data are presented as the mean \pm SD. Data were analyzed using SPSS statistical software. Statistical analyses were performed by one way analysis of variance (ANOVA). Significant differences between means were tested by the least significant difference (LSD) at $P \leq 0.05$.

\section{Results:-}

After 3 days exposure to different metal concentrations, Data in Table (1) clearly demonstrate an increase in Cd accumulation in Ulva linza by increasing the metal concentration. Cd concentration in control treatment was negligible or below the detection limit. The BCF of Cd by $\mathrm{U}$. linza attained a peak at $300 \mu \mathrm{M} \mathrm{Cd}$ above which no further increase in BCF was observed.

Moreover, Treatment with $50 \mu \mathrm{M}$ Cd did not change DGR of U. linza compared to its control. The DGR was significantly decreased as $\mathrm{Cd}$ concentration increased. Exposure to 100, 200, 300 and $400 \mu \mathrm{M}$ Cd caused decline in DGR by $14,25,36$, and $49 \%$, respectively.

With reference to the control, results in Table (1) show that no obvious significant differences in $\mathrm{Fv} / \mathrm{Fm}$ at 50 and $100 \mu \mathrm{M} \mathrm{Cd}$ was noticed, while it showed declining trend by 19,32 and $48 \%$ at 200,300 and $400 \mu \mathrm{M} \mathrm{Cd}$, respectively.

It was noteworthy that varying concentrations of $\mathrm{Cd}$ had a pronounced effect on protein content of $\mathrm{U}$. linza. In relative to the control, the lowest studied Cd concentration $(50 \mu \mathrm{M})$ did not cause significant change in protein content of $\mathrm{U}$. linza, while the Cd concentrations of 100, 200, 300 and $400 \mu \mathrm{M}$ decreased protein content by 9, 15, 22 and $28 \%$, respectively. 
On the other hand, as the concentration of Cd increased, there was a conspicuous increase in proline content of the investigated alga. At lowest studied Cd concentration, proline content of $\mathrm{U}$. linza increased by 1.3 fold of the control, whereas it rose sharply when Cd concentration exceeded $50 \mu \mathrm{M}$ and attained a peak of 4.2 fold of the control at $300 \mu \mathrm{M}$.

U. linza showed a modest increase in $\mathrm{H}_{2} \mathrm{O}_{2}$ content upon exposure to studied Cd concentrations. In relative to the control, a maximum $\mathrm{H}_{2} \mathrm{O}_{2}$ content was $39 \%$ at the highest studied $\mathrm{Cd}$ concentration. Taking into consideration that the alga did not show significant difference in $\mathrm{H}_{2} \mathrm{O}_{2}$ content between 50 and 100 as well as between 200 and $300 \mu \mathrm{M}$ Cd treatments.

The lipid peroxidation, indicated by the level of MDA content, in the investigated alga was generally increased upon exposure to all $\mathrm{Cd}$ concentrations and reached the maximum (48\%) at $400 \mu \mathrm{M} \mathrm{Cd}$. Moreover, no significant difference regarding to MDA content between 50 and $100 \mu \mathrm{M} \mathrm{Cd}$ treatments.

In order to investigate the responses of their reactive oxygen scavenging systems following exposure to $\mathrm{Cd}$ for 3 days, the activities of several antioxidant enzymes were measured (Table 2). The results demonstrate an increase in SOD activity in a metal concentration-dependent manner. Since compared to the control, SOD activity of U. linza increased by $12 \%$ at $50 \mu \mathrm{M} \mathrm{Cd}$ and continued to increase up to $96 \%$ at $400 \mu \mathrm{M} \mathrm{Cd}$. A considerable increase in APX activity by $49 \%$ and $67 \%$ compared to the control at 50 and $100 \mu \mathrm{M} \mathrm{Cd}$, respectively. Then it increased reaching up147, 191 and $160 \%$ compared to the control at 200,300 and $400 \mu \mathrm{M} \mathrm{Cd}$, respectively. As compared to the control, low Cd concentrations $(50$ and $100 \mu \mathrm{M})$ did not significantly change the CAT activity of U. linza, whereas it was enhanced sharply and progressively with increasing of Cd concentration $>100 \mu \mathrm{M}$. Since the alga achieved significant increases in CAT activity by 86,129 and $193 \%$ at 200,300 and $400 \mu \mathrm{M} \mathrm{Cd}$, respectively. The GR activity of $\mathrm{U}$. linza increased upon exposure to $\mathrm{Cd}$ in all treatments and attained a peak at $200 \mu \mathrm{M} \mathrm{Cd}$. As compared to the control, increase of GR activity was $26,52,220,98$ and $39 \%$ at 50,100, 200, 300 and $400 \mu \mathrm{M} \mathrm{Cd}$, respectively.

For all Cd treatments, the results in Table (2) show that U. Linza exhibited noticeable increase in SOD transcript reaching the maximum at $400 \mu \mathrm{M}$. This increase was 1.40 fold of the control at $50 \mu \mathrm{M} \mathrm{Cd}$ and remained the same up to $200 \mu \mathrm{M} \mathrm{Cd}$. Afterward, it elevated to 2.05 and 2.73 fold at 300 and $400 \mu \mathrm{M} \mathrm{Cd}$, respectively. The APX transcript of U. linza was stimulated markedly by all studied Cd concentrations and attained a peak (3.6 fold of the control) at $200 \mu \mathrm{M} \mathrm{Cd}$. Taking into account that there was no significant difference between 300 and $400 \mu \mathrm{M}$ Cd regarding to APX gene transcript of U. linza. Stimulation in CAT transcript with increasing of Cd concentration was observed in U. linza. The alga showed increase in CAT transcript graded from 1.16 fold of the control at $50 \mu \mathrm{M} \mathrm{Cd}$ to 4.31 fold of the control at $400 \mu \mathrm{M} \mathrm{Cd}$. The results indicated a conspicuous increase in the GR transcript of $\mathrm{U}$. linza upon exposure to all studied Cd concentrations. This increase attained a peak of 4.15 fold of the control at $200 \mu \mathrm{M} \mathrm{Cd}$.

Data in Table (3) displayed the AsA, DHA and AsA/DHA ratio of U. linza after exposure to various concentrations of $\mathrm{Cd}$ for 3 days. AsA content of $\mathrm{U}$. linza was significantly increased by treatments with $50-400 \mu \mathrm{M} \mathrm{Cd}$. This increase ranged from 31 to $63 \%$ and attained a peak at200 $\mu \mathrm{M} \mathrm{Cd}$. The DHA content also increased but its increment was less than that of AsA. Where, it was not affected by the lowest Cd concentration ( $50 \mu \mathrm{M} \mathrm{Cd})$ and it rose gradually by 13, 24, 29 and $36 \%$ over the control with increasing of Cd concentration from 100 to $400 \mu \mathrm{M}$. The ratio of AsA/DHA for $\mathrm{U}$. linza achieved increase of 28, 33, 31, 7\% over the control when the alga exposed to 50, 100,200 and $300 \mu \mathrm{M} \mathrm{Cd}$, respectively, while its value did not change significantly at $400 \mu \mathrm{M} \mathrm{Cd}$.

Moreover, the results indicated a steady slight decrease in GSH content of U. linza by 50-300 $\mu \mathrm{M}$ Cd treatments. This decrease elevated to a significant value (21\%) at the highest Cd concentration $(400 \mu \mathrm{M})$. Cd concentrations did not significantly affect the GSSG content of U. Linza except for $18 \%$ decline at $300 \mu \mathrm{M} \mathrm{Cd}$. Similarly, the GSH/GSSG ratio of U. linza was not significantly influenced by any of Cd concentrations, except the highest one $(400 \mu \mathrm{M})$, which decreased it by $23 \%$ than control.

The results clearly demonstrated that Cd-induced stimulation of antioxidant activity of $\mathrm{U}$. linza. For the range of $\mathrm{Cd}$ concentration studied $(50-400 \mu \mathrm{M})$, U. linza exhibited a considerable increase in its antioxidant activity increased to 1.84 fold of the control at $300 \mu \mathrm{M} \mathrm{Cd}$. 


\section{Discussion:-}

The bio-concentration factor is a useful parameter to evaluate the potential of plants for accumulating metals and this value was calculated on a dry weight basis (Raskin et al., 1994). It is known that marine macroalgae can accumulate heavy metals to a large extent (Baumann et al., 2009 ; Jiang et al., 2013). Results showed that the accumulation of $\mathrm{Cd}$ by treated the alga was parallel to increasing its concentration in the culture medium. It is known that algal cell walls are often porous and allow the free passage of molecules and ions in aqueous solutions (Hope and Walker, 1975). In addition, the constituents of the cell wall provide an array of ligands with a mosaic of functional groups capable of binding various metallic ions. Indeed, it has been shown that many metal binding mechanisms are involved in the biosorption process; these include ion exchange, complexation, coordination, and microprecipitation (Chen et al., 2002 ; Flores-Garnica et al., 2013). In view of the structure complexity of the algal surfaces, it is possible that several of these mechanisms occur simultaneously to varying degrees, depending on the biosorbent and the aqueous environment. $\mathrm{Cd}$ is a non- essential element for growth, the plants may actively exclude or sequester such to minimize the metal toxic impact (Xia et al., 2004 ; Williams and Salt, 2009).

Growth rate is an important way for expressing the relative ecological success of a species or strain in adapting to its natural environment or the experimental environment imposed upon it. In the present study, the DGR of U. linza exposed to $\mathrm{Cd}$ for 3 days generally decreased with increasing of metal concentration. Heavy metal ions could interrupt routine metabolic processes by competing for the protein binding sites, activate enzymes and various biological reactive groups, causing poor or no growth (Arunakumara and Xuecheng, 2008 ; Narula et al., 2015). At the same time, the decrease in growth rates of algae may be attributed to the use of energy for activation of adaptation mechanisms and repair of damage induced by metal stress. It could be suggested that heavy metal ions can inhibit the growth of algae in different ways, which depend on the species, the metal types and the conditions in the growing media.

In the present study, Fv/Fm was used to indicate the influence of metals on the photosynthetic efficiency of the investigated alga. Since the measurement of Fv/Fm provide a first insight into changes of the photosynthetic apparatus upon the action of the metals (Sbihi et al., 2012) and can reveal the mechanisms implicated in metals toxicity (Miao et al., 2005). In general, the Fv/Fm of U. linza decreased gradually with increasing of Cd concentration. It is known that heavy metals could sorely affect the photosynthetic apparatus by irreversibly binding the components of photosynthetic electron transport chain. For instance, $\mathrm{Cd}$ can substitutes $\mathrm{Mg}$ in the center of chlorophyll molecule leading to termination of photosynthesis activity by forming non-fluorescent inactive metals substituted chlorophyll (Sharma and Dietz, 2009; Dietz and Pfannschmidt, 2011).

The pattern of metal effect on protein looked like that was observed on growth and photosynthetic efficiency, where in general, the effect negatively escalated as much as the concentration increased. The decline in protein represents the growth inhibition occurred. In addition the reduction of protein content may be attributed to the shortage of carbon skeleton resulting from low photosynthetic rate (Afkar et al., 2010 ; Carfagna et al., 2013). It is also likely that the heavy metals may cause fragmentation of protein due to toxic effects of ROS, which led to reduced protein content.

The reactive oxygen species and lipid peroxidation are the well known indices for determining the degree of oxidative stress and considered main contributors for growth retardation (Blokhina et al., 2003). In the present study, increase in $\mathrm{H}_{2} \mathrm{O}_{2}$ and $\mathrm{MAD}$ (end products of lipid peroxidation) contents with increasing Cd concentration was obvious for Ulva linza. This suggests that the toxic effect of heavy metals is probably exerted through free radical generation. In higher plants, heavy metals induce generation of superoxide radical $\left(\mathrm{O}_{2}{ }^{-}\right)$, hydrogen peroxide $\left(\mathrm{H}_{2} \mathrm{O}_{2}\right)$, hydroxyl radical $\left(\mathrm{OH}^{\circ}\right)$, and singlet oxygen $\left({ }^{1} \mathrm{O}_{2}\right)$, collectively termed ROS, and exert a variety of damaging effects, also called oxidative stress (Devi and Prasad, 1998). In contrast to higher plant, algae and cyanobacteria have not been studied extensively with regard to generation of free radicals under stressed conditions. The ROS can rapidly attack all types of biomolecules such as nucleic acids, proteins, lipids, and amino acids (Hu et al., 2007 ; Yadav, 2010). This leading to irreclaimable metabolic dysfunction and cell death when the ROS metabolism cannot cope the increased amounts of the formed ROS.

Heavy metals are implicated in oxidative injury as a result of the formation of ROS. The protective mechanisms adopted by plants to scavenge free radicals and peroxides include several antioxidant enzymes and antioxidant substances (Collén et al., 2003; Ahmad et al., 2010). 
Studies on the regulation of antioxidant enzymes at the molecular levels are limited in macroalgae. De Oliveira e Silva et al., (2012) showed an increase in the catalase gene expression by RT/PCR analysis in the group treated with free phenolic acid (FPA) fractions from Halimeda opuntia, suggesting the inductor effect of these compounds on the enzyme genes. Hou et al.,(2018) presented a new issue related to nanoparticles the impact of which is not known and their use in industry is increasing. Researchers report that inhibition of Chlorella sp. algae influenced by zinc nanoparticles has been observed.

So in the attempts to answer the question, whether studied metal can induce the gene expression of antioxidant enzymes, the genes SOD, APX, CAT and GR were cloned from U. linza and transcript abundance in response to Cd was examined.

Amongst various enzymes involved in the abolition of ROS, SOD can be considered as a key enzyme. SOD being a fundamental component of antioxidative defense system in plants. It converts $\mathrm{O}_{2}{ }^{-}$to $\mathrm{H}_{2} \mathrm{O}_{2}$ at a very quick rate (Alscher et al., 2002). The increase in SOD activity might be attributed to the elevated production of superoxide radicles, thus resulting in activation of existing enzyme pools or up-regulated expression of the gene (Elbaz et al., 2010). To ensure the possibility, analyzing the transcripts of Fe-SOD coding one of SOD isoforms in algae were done. The expression of Fe-SOD in U. linza was up-regulated by Cd exposure and these results suggest that SOD can be regulated by $\mathrm{Cd}$ at molecular level in addition to enzymatic activity.

Cellular $\mathrm{H}_{2} \mathrm{O}_{2}$ generated by SOD mediated reaction is highly toxic and must be tightly controlled at low levels. In plants, a number of enzymes regulates intracellular $\mathrm{H}_{2} \mathrm{O}_{2}$ levels. CAT and APX are considered the most dominant enzymes that catalyze $\mathrm{H}_{2} \mathrm{O}_{2}$ to $\mathrm{H}_{2} \mathrm{O}$ or the other non-toxic products (Nakano and Asada, 1981; Del Rìo et al., 2006).

The main hydrogen peroxide-detoxification system in plant chloroplasts is the ascorbate-glutathione cycle. In this cycle APX is a key enzyme uses AsA as specific electron donor to reduce $\mathrm{H}_{2} \mathrm{O}_{2}$ to water (Asada, 1992). As CAT is absent in the chloroplast, so degradation of $\mathrm{H}_{2} \mathrm{O}_{2}$ is catalyzed by APX in chloroplasts. Moreover APX has a higher affinity for $\mathrm{H}_{2} \mathrm{O}_{2}$ than CAT so it plays a more substantial role in the $\mathrm{H}_{2} \mathrm{O}_{2}$ scavenging during stress (Wang et al.,1999 ; Gill and Tuteja, 2010). The enhancement of APX transcripts in U. linza upon exposure to Cd supported the regulation of APX activity at the transcriptional level. This explains that the Cd-triggered antioxidative capacity might be responsible for the removal of excessive $\mathrm{H}_{2} \mathrm{O}_{2}$.

Catalase is one of the most important components of plant protective mechanisms that catalyzing $\mathrm{H}_{2} \mathrm{O}_{2}$ to $\mathrm{H}_{2} \mathrm{O}$ and $\mathrm{O}_{2}$ via two-electron transfer (Srivalli et al., 2003 ; Wang et al., 2008) hence, prevent the generation of $\mathrm{OH}^{*}$ and protect proteins, nucleic acids and lipids against ROS (Imlay and Linn, 1988).CAT provides an energy efficient mechanism to degrade $\mathrm{H}_{2} \mathrm{O}_{2}$, thereby it removes $\mathrm{H}_{2} \mathrm{O}_{2}$ without consuming cellular reducing equivalents such as NADPH (Mallick and Mohn, 2000).

Glutathione reductase is another key enzyme in the ascorbate-glutathione cycle that protects cells against oxidative damage. GR is a flavo-protein oxidoreductase, which catalyses the reduction of GSSG to the sulphydryl form GSH, employs NADPH as a reductant (Jiménez et al., 1997). GR activity is important to maintain a high GSH/GSSG ratio, being substantial to the functioning of the glutathione-ascorbate cycle and phytochelatin synthesis (Cobbett, 2000), which in turn are responsible for the tolerance of the species to contamination by heavy metal (Benavides et al.,2005). The activity and transcript of GR in this work were consistently reflecting the transcriptional regulation of GR activity by studied metal.

Since antioxidant enzymes are the first strategy in plants to detoxify heavy metals and scavenge ROS, the low molecular weight non-enzymatic antioxidants such as ascorbic acid, glutathione and proline, are considered as the second strategy.

AsA plays a great role in minimizing the damage caused by the oxidative process. This is carried out by its synergetic action with other antioxidants (Foyer and Noctor, 2005). A fundamental role of AsA in the plant defense system is to protect metabolic processes against $\mathrm{H}_{2} \mathrm{O}_{2}$ and other toxic derivatives of oxygen. AsA can function essentially as reductant and scavenges many types of free radicals. AsA can directly scavenge $\mathrm{O}_{2}{ }^{-}, \mathrm{H}_{2} \mathrm{O}_{2}$ and $\mathrm{OH}^{*}$ and regenerate tocopherol from tocopheroxyl radical, thus providing membrane protection (Smirnoff, 1996; Shao et al., 2007). In addition, it is the most important reducing substrate for $\mathrm{H}_{2} \mathrm{O}_{2}$ detoxification in ascorbate-glutathione cycle (Smirnoff, 1996; Moucheshi et al., 2014). Moreover, the AsA/DHA ratio, an important indicator of the redox 
status of cells, is one of the first signs of oxidative stress (Foyer et al., 2006). In present study, the regeneration of AsA leading to maintenance of AsA/DHA ratio larger than or equal to control.

GSH is a key component in the metal scavenging due to the high affinity of metals to its thiol (-SH) group and as a precursor of phytochelatins (PCs), which are responsible for controlling cellular heavy metal concentration by forming heavy metal complexes (Yadav, 2010). Besides metal homeostasis, GSH is considered an important antioxidant because it is a key ROS scavenger and major cellular redox buffer, in addition to its primary antioxidant capacities; it acts as a substrate for the regeneration of other essential antioxidants (Foyer and Noctor, 2005 ; Bashandy et al., 2010). The GSH can act directly as a free radical scavenger by reacting with other $\mathrm{ROS},{ }^{1} \mathrm{O}_{2}, \mathrm{O}_{2}{ }^{--}$, and $\mathrm{OH}^{\circ}$. In addition, GSH can form non-enzymatic conjugates with a great variety of reactive electrophiles, hence protect the cellular macro molecules (Larson, 1988 ; Asada, 1994). Furthermore, GSH contributes in the control of $\mathrm{H}_{2} \mathrm{O}_{2}$ levels in the ascorbate-glutathione cycle through the regeneration of AsA (Smeets et al.,2009). In this way, GSH/GSSG ratio plays an important role in indicating cellular redox status (Smeets et al., 2005) and cellular responses under environmental stress conditions (Foyer and Noctor , 2011 ; Seth et al., 2012). Therefore, availability of glutathione (i.e., a high GSH/GSSG ratio) is very necessary for plants exposed to oxidative stress such induced by heavy metals (Israr et al., 2006).

Plants have been shown proline accumulation under environmental stress (Delmail, et al., 2011 ; Joseph et al., 2015). The present work thus clearly represents the protective role of proline against metal toxicity, although it is difficult to elaborate the manner in which this role was executed. It might be that proline forms complexes with metal ions thereby protecting sensitive cellular sites from toxic effects. Alternatively, proline might sequester the harmful radicals (Mallick, 2004). It has been suggested to act as a hydroxyl radical scavenger (Smirnoff and Cumbes, 1989; Signorelli et al., 2014), and a singlet oxygen scavenger (Matysik et al., 2002). In addition, proline synthesis has been involved in the mitigation of cytoplasmic acidosis and may maintain NADP /NADPH ratios at values compatible with metabolism (Hare and Cress, 1997). Moreover, proline maintains the water balance in the cell, which is often disturbed by heavy metals (Mallick, 2004).

\section{Conclusion:-}

Based on the current work, it could be concluded that U. linza was effective biosorbent for removal of Cd from aqueous solution. The decreased growth rate, photosynthetic efficiency and protein contents with corresponding increase in lipid peroxidation (MAD content) and $\mathrm{H}_{2} \mathrm{O}_{2}$ content following the exposure to Cd indicates that the ROS generation confirming the state of oxidative stress.

The antioxidant homeostasis, represented by antioxidant enzymes and non-enzymatic antioxidants is markedly altered by $\mathrm{Cd}$ in order to prevent or alleviate oxidative damage. The activities and transcripts of SOD, APX and GR were a consistent reflecting the transcriptional regulation of SOD, APX and GR activities by Cd. This, in general, indicates that the tolerance capacity of alga to $\mathrm{Cd}$ depends on an interrelated network of physiological and molecular mechanisms.

According to the results of the present study and since Ulva linza has some important aspects, such as their rapid growing along Alexandria sea shore and the possibility of controlling the production of some bioactive compounds by manipulating the cultivation conditions the present study suggests the possibility of using the heavy metal in improving the production of antioxidants from algae.

Table 1:-Data on BCF, DGR,Photosynthetic Efficiency, Total Protein, Proline, $\mathrm{H}_{2} \mathrm{O}_{2}$ and MDA content of U. linza following its exposure to $\mathrm{Cd}$ for 3 days (means $\pm \mathrm{SD}, \mathrm{n}=3$ ).

\begin{tabular}{|c|c|c|c|c|c|c|c|}
\hline $\begin{array}{l}\text { Cd Conc. } \\
(\mu \mathrm{M})\end{array}$ & (BCF) & $\begin{array}{l}\text { (DGR) } \\
(\%)\end{array}$ & $\mathrm{Fv} / \mathrm{Fm}$ & $\begin{array}{l}\text { Total } \\
\text { Protein } \\
\left(\mathrm{mgg}^{-1} \mathrm{DW}\right)\end{array}$ & $\begin{array}{l}\text { Proline } \\
\left(\mu g^{-1} \mathrm{DW}\right)\end{array}$ & $\begin{array}{c}\mathrm{H}_{2} \mathrm{O}_{2} \\
\left(\mu \mathrm{mol} \cdot \mathrm{g}^{-1} \mathrm{DW}\right)\end{array}$ & $\begin{array}{l}\text { MDA } \\
\left(\text { nmol.g }{ }^{-1} \mathrm{DW}\right)\end{array}$ \\
\hline 0 & - & $\begin{array}{l}4.158^{a} \\
\pm 0.215\end{array}$ & $\begin{array}{l}0.770^{a} \\
\pm 0.014\end{array}$ & $\begin{array}{l}148.079^{a} \\
\pm 5.726\end{array}$ & $\begin{array}{l}86.383 \\
\pm 4.274\end{array}$ & $\begin{array}{l}0.734^{\mathrm{c}} \\
\pm 0.034\end{array}$ & $\begin{array}{l}18.250^{d} \\
\pm 1.268\end{array}$ \\
\hline 50 & $\begin{array}{l}0.560^{c} \\
\pm 0.028\end{array}$ & $\begin{array}{l}4.344^{\mathrm{a}} \\
\pm 0.631\end{array}$ & $\begin{array}{l}0.736^{\mathrm{a}} \\
\pm 0.027\end{array}$ & $\begin{array}{l}139.715^{a} \\
\pm 6.774\end{array}$ & $\begin{array}{l}113.596^{\mathrm{e}} \\
\pm 9.246\end{array}$ & $\begin{array}{l}\mathbf{O . 8 1 3}^{\mathrm{bc}} \\
\pm 0.023\end{array}$ & $\begin{array}{l}20.615^{\mathrm{cd}} \\
\pm 1.646\end{array}$ \\
\hline 100 & $\begin{array}{l}\mathbf{0 . 6 8 3} \\
\pm 0.049\end{array}$ & $\begin{array}{l}\mathbf{3 . 5 5 8} \\
\pm \mathbf{0 . 3 8} \\
\end{array}$ & $\begin{array}{l}0.717^{\text {a }} \\
\pm 0.036\end{array}$ & $\begin{array}{l}134.712^{\mathrm{ab}} \\
\pm 5.152\end{array}$ & $\begin{array}{l}219.844^{c} \\
\pm 6.587\end{array}$ & $\begin{array}{l}\mathbf{0 . 8 3 5} \\
\pm 0.047\end{array}$ & $\begin{array}{l}21.323^{\text {cd }} \\
\pm 2.150\end{array}$ \\
\hline
\end{tabular}




\begin{tabular}{|c|c|c|c|c|c|c|c|}
\hline 200 & $\begin{array}{l}0.770^{\text {ab }} \\
\pm 0.029 \\
\end{array}$ & $\begin{array}{l}3.103^{\text {bc }} \\
\pm 0.184 \\
\end{array}$ & $\begin{array}{l}\mathbf{0 . 6 1 8}^{\mathrm{b}} \\
\pm 0.003 \\
\end{array}$ & $\begin{array}{l}125.008^{\text {bc }} \\
\pm 6.058\end{array}$ & $\begin{array}{l}2^{274.258}{ }^{b} \\
\pm 12.441 \\
\end{array}$ & $\begin{array}{l}0.917^{\text {ab }} \\
\pm 0.035 \\
\end{array}$ & $\begin{array}{l}2^{23.291}{ }^{\mathrm{bc}} \\
\pm 1.184 \\
\end{array}$ \\
\hline 300 & $\begin{array}{l}0.812^{a} \\
\pm 0.059\end{array}$ & $\begin{array}{l}2.624^{\mathrm{cd}} \\
\pm 0.304\end{array}$ & $\begin{array}{l}0.518^{c} \\
\pm 0.052\end{array}$ & $\begin{array}{l}115.804^{\text {cd }} \\
\pm 3.659\end{array}$ & $\begin{array}{l}369.065^{\mathrm{a}} \\
\pm 8.680\end{array}$ & $\begin{array}{l}0^{0.973}{ }^{\text {ab }} \\
\pm 0.043\end{array}$ & $\begin{array}{l}25.142^{\text {ab }} \\
\pm 1.488\end{array}$ \\
\hline 400 & $\begin{array}{l}0.765^{a b} \\
\pm 0.064\end{array}$ & $\begin{array}{l}2.103^{d} \\
\pm 0.165\end{array}$ & $\begin{array}{l}0.393 \\
\pm 0.024\end{array}$ & $\begin{array}{l}105.939 \\
\pm 4.648\end{array}$ & $\begin{array}{l}180.215^{d} \\
\pm 9.199\end{array}$ & $\begin{array}{l}1.023^{a} \\
\pm 0.059\end{array}$ & $\begin{array}{l}27.038^{\mathrm{a}} \\
\pm 1.735\end{array}$ \\
\hline
\end{tabular}

Table 2:-The activities and transcript of SOD, APX, CAT and GR in Ulvalinzain response to elevated Cd concentrations for 3 days (means $\pm \mathrm{SD}, \mathrm{n}=3$ ).

\begin{tabular}{|c|c|c|c|c|c|c|c|c|}
\hline \multirow[t]{2}{*}{$\begin{array}{l}\text { CdConc. } \\
(\mu \mathrm{M})\end{array}$} & \multicolumn{4}{|c|}{$\begin{array}{l}\text { Enzyme Activity } \\
\left(\mathrm{Umg}^{-1} \mathrm{pr}\right)\end{array}$} & \multicolumn{4}{|c|}{$\begin{array}{l}\text { RelativeTranscript Level of Enzyme } \\
\text { (Fold of the Initial Control) }\end{array}$} \\
\hline & SOD & APX & CAT & GR & SOD & APX & CAT & GR \\
\hline 0 & $\begin{array}{l}162.530 \\
\pm 7.904\end{array}$ & $\begin{array}{l}0.253^{d} \\
\pm 0.035\end{array}$ & $\begin{array}{l}0.448^{d} \\
\pm 0.052\end{array}$ & $\begin{array}{l}0.412^{d} \\
\pm 0.000\end{array}$ & $\begin{array}{l}1.000^{d} \\
\pm 0.000\end{array}$ & $\begin{array}{l}1.000^{d} \\
\pm 0.000\end{array}$ & $\begin{array}{l}1.000^{\mathrm{e}} \\
\pm 0.000\end{array}$ & $\begin{array}{l}1.000^{d} \\
\pm 0.000\end{array}$ \\
\hline 50 & $\begin{array}{l}182.436^{\text {ed }} \\
\pm 16.611\end{array}$ & $\begin{array}{l}0.376^{c} \\
\pm 0.048\end{array}$ & $\begin{array}{l}0.475^{d} \\
\pm 0.088\end{array}$ & $\begin{array}{l}0.519^{\mathrm{cd}} \\
\pm 0.066\end{array}$ & $\begin{array}{l}1.399^{c} \\
\pm 0.171\end{array}$ & $\begin{array}{l}1.651^{\mathrm{c}} \\
\pm 0.126\end{array}$ & $\begin{array}{l}1.163^{\text {de }} \\
\pm 0.102\end{array}$ & $\begin{array}{l}1.731^{\mathrm{c}} \\
\pm 0.158\end{array}$ \\
\hline 100 & $\begin{array}{l}196.1388^{d} \\
\pm 10.965\end{array}$ & $\begin{array}{l}0.423^{c} \\
\pm 0.045\end{array}$ & $\begin{array}{l}0.602^{\mathrm{d}} \\
\pm 0.042\end{array}$ & $\begin{array}{l}0.628^{\mathrm{c}} \\
\pm 0.037\end{array}$ & $\begin{array}{l}1.475^{\mathrm{c}} \\
\pm 0.113\end{array}$ & $\begin{array}{l}2.119^{b} \\
\pm 0.196\end{array}$ & $\begin{array}{l}1.511^{d} \\
\pm 0.126\end{array}$ & $\begin{array}{l}3.098^{b} \\
\pm 2.772\end{array}$ \\
\hline 200 & $\begin{array}{l}238.724^{\mathrm{c}} \\
\pm 14.795\end{array}$ & $\begin{array}{l}0.625^{b} \\
\pm 0.05\end{array}$ & $\begin{array}{l}0.832^{\mathrm{c}} \\
\pm 0.066\end{array}$ & $\begin{array}{l}1.319^{a} \\
\pm 0.075\end{array}$ & $\begin{array}{l}1.547^{\mathrm{c}} \\
\pm 0.160\end{array}$ & $\begin{array}{l}3.665^{\mathrm{a}} \\
\pm 2.135\end{array}$ & $\begin{array}{l}2.056^{c} \\
\pm 0.164\end{array}$ & $\begin{array}{l}4.147^{\mathrm{a}} \\
\pm 0.199\end{array}$ \\
\hline 300 & $\begin{array}{l}276.541^{b} \\
\pm 6.094\end{array}$ & $\begin{array}{l}0.736^{\mathrm{a}} \\
\pm 0.000\end{array}$ & $\begin{array}{l}1.027^{b} \\
\pm 0.10\end{array}$ & $\begin{array}{l}0.817^{b} \\
\pm 0.039\end{array}$ & $\begin{array}{l}2.051^{b} \\
\pm 0.156\end{array}$ & $\begin{array}{l}2.284^{b} \\
\pm 0.193\end{array}$ & $\begin{array}{l}2.827^{b} \\
\pm 0.148\end{array}$ & $\begin{array}{l}2.847^{b} \\
\pm 0.185\end{array}$ \\
\hline 400 & $\begin{array}{l}318.437^{a} \\
\pm 18.264\end{array}$ & $\begin{array}{l}0.659^{\text {ab }} \\
\pm 0.060\end{array}$ & $\begin{array}{l}1.311^{\mathrm{a}} \\
\pm 0.083\end{array}$ & $\begin{array}{l}0.574^{c} \\
\pm 0.043\end{array}$ & $\begin{array}{l}2.738^{a} \\
\pm 0.200\end{array}$ & $\begin{array}{l}\text { 2.321 }^{b} \\
\pm 0.153\end{array}$ & $\begin{array}{l}4.314^{a} \\
\pm 0.281\end{array}$ & $\begin{array}{l}1.982^{c} \\
\pm 0.201\end{array}$ \\
\hline
\end{tabular}

Table 3:-Levels of AsA, DHA, AsA/DHA ratio and levels of GSH, GSSG, GSH/GSSG ratio and antioxidant activityinUlvalinzain response to elevated Cd concentrations for 3 days (means $\pm \mathrm{SD}, \mathrm{n}=3$ ).

\begin{tabular}{|c|c|c|c|c|c|c|c|c|}
\hline \multirow[t]{2}{*}{$\begin{array}{l}\text { Cd Conc. } \\
(\mu \mathrm{M})\end{array}$} & \multicolumn{3}{|c|}{ Ascorbate Pool } & \multicolumn{3}{|c|}{ Glutathione Pool } & \multicolumn{2}{|c|}{$\begin{array}{l}\text { Antioxidant } \\
\text { activity } \\
(\%)\end{array}$} \\
\hline & $\begin{array}{l}\text { AsA } \\
\left(\mu M_{1} g^{-}\right. \\
\left.{ }^{1} \mathbf{D W}\right)\end{array}$ & $\begin{array}{l}\text { DHA } \\
\left(\mu \mathbf{M}^{-}\right. \\
\left.{ }^{1} \mathrm{DW}\right)\end{array}$ & AsA/DHA & $\begin{array}{l}\text { GSH } \\
\mu M_{1} g^{-} \\
{ }^{1} \text { DW }\end{array}$ & 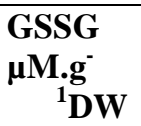 & GSH/GSSG & 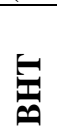 & $\begin{array}{l}91.384^{\mathrm{a}} \\
\pm 2.349\end{array}$ \\
\hline 0 & $\begin{array}{l}6.631^{\mathrm{d}} \\
\pm 0.417 \\
\end{array}$ & $\begin{array}{l}6.907^{\mathrm{c}} \\
\pm 0.427 \\
\end{array}$ & $\begin{array}{l}0.960^{\mathrm{c}} \\
\pm 0.087 \\
\end{array}$ & $\begin{array}{l}1.598^{\mathrm{a}} \\
\pm 0.132 \\
\end{array}$ & $\begin{array}{l}1.182^{\text {ab }} \\
\pm 0.095 \\
\end{array}$ & $\begin{array}{l}1.352^{a} \\
\pm 0.093 \\
\end{array}$ & \multirow{6}{*}{ 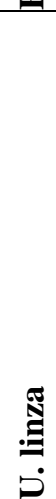 } & $\begin{array}{l}4^{43.013}{ }^{\mathrm{f}} \\
\pm 2.301 \\
\end{array}$ \\
\hline 50 & $\begin{array}{l}8.664^{\mathrm{c}} \\
\pm 0.535\end{array}$ & $\begin{array}{l}7.041^{\mathrm{c}} \\
\pm 0.503\end{array}$ & $\begin{array}{l}1.231^{\text {ab }} \\
\pm 0.116\end{array}$ & $\begin{array}{l}1.547^{\mathrm{ab}} \\
\pm 0.143\end{array}$ & $\begin{array}{l}1.132^{\text {ab }} \\
\pm 0.116\end{array}$ & $\begin{array}{l}1.366^{\mathrm{a}} \\
\pm 0.107\end{array}$ & & $\begin{array}{l}54.637^{\mathrm{e}} \\
\pm 2.626\end{array}$ \\
\hline 100 & $\begin{array}{l}9.972^{\text {ab }} \\
\pm 0.304\end{array}$ & $\begin{array}{l}7.791^{\mathrm{bc}} \\
\pm 0.346\end{array}$ & $\begin{array}{l}1.280^{a} \\
\pm 0.085\end{array}$ & $\begin{array}{l}1.489^{\mathrm{ab}} \\
\pm 0.126\end{array}$ & $\begin{array}{l}1.075^{\text {ab }} \\
0.081\end{array}$ & $\begin{array}{l}1.385^{\mathrm{a}} \\
\pm 0.094\end{array}$ & & $\begin{array}{l}69.750 \\
\pm 1.526\end{array}$ \\
\hline 200 & $\begin{array}{l}10.814^{a} \\
\pm 0.607\end{array}$ & $\begin{array}{l}8.588^{\text {ab }} \\
\pm 0.717\end{array}$ & $\begin{array}{l}1.259^{\text {ab }} \\
\pm 0.114\end{array}$ & $\begin{array}{l}1.438^{\mathrm{ab}} \\
\pm 0.096\end{array}$ & $\begin{array}{l}1.025^{\mathrm{ab}} \\
\pm 0.090\end{array}$ & $\begin{array}{l}1.403^{\mathrm{a}} \\
\pm 0.091\end{array}$ & & $\begin{array}{l}74.400 \text { bc } \\
\pm 2.108\end{array}$ \\
\hline 300 & $\begin{array}{l}9.190^{\mathrm{bc}} \\
\pm 0.594\end{array}$ & $\begin{array}{l}8.932^{\mathrm{ab}} \\
\pm 0.609\end{array}$ & $\begin{array}{l}1.029^{b c} \\
\pm 0.089\end{array}$ & $\begin{array}{l}1.332^{\text {ab }} \\
\pm 0.093 \\
\end{array}$ & $\begin{array}{l}0.966^{b} \\
\pm 0.074\end{array}$ & $\begin{array}{l}1.379^{a} \\
\pm 0.081\end{array}$ & & $\begin{array}{l}79.104^{b} \\
\pm 3.033\end{array}$ \\
\hline 400 & $\begin{array}{l}8.332^{c} \\
\pm 0.564 \\
\end{array}$ & $\begin{array}{l}9.395^{a} \\
\pm 0.560 \\
\end{array}$ & $\begin{array}{l}0.887^{\mathrm{c}} \\
\pm 0.071 \\
\end{array}$ & $\begin{array}{l}1.253^{b} \\
\pm 0.122 \\
\end{array}$ & $\begin{array}{l}1.213^{a} \\
\pm 0.105 \\
\end{array}$ & $\begin{array}{l}1.033^{b} \\
\pm 0.103 \\
\end{array}$ & & $\begin{array}{l}6^{63.937^{d}} \\
\pm 3.520 \\
\end{array}$ \\
\hline
\end{tabular}

\section{References:-}

1. Aebi, H. (1984): Catalase in vitro. Methods in Enzymology., 105:121- 126.

2. Afkar, E., Ababna, H. and Fathi, A.A. (2010): Toxicological response of the green alga Chlorella vulgaris to some heavy metals. American Journal of Environmental Sciences., 6 (3): 230-237.

3. Ahmad, P., Abdul Jaleel, C., Salem, M.A., Nabi, G. and Sharma, S. (2010): Roles of enzymatic and non enzymatic antioxidants in plants during abiotic stress. Critical Reviews in Biotechnology., 30(3): 161-175.

4. Alscher, R.G., Erturk, N. and Heath, L.S. (2002): Role of superoxide dismutases (SODs) in controlling oxidative stress in plants. Experimental Botany., 53:1331-1341. 
5. Arunakumara, K.K.I.U. and Xuecheng, Z. (2008): Heavy metal bioaccumulation and toxicity with special reference to microalgae. Journal of Ocean University of China., 7(1): 25-30.

6. Asada, K. (1992):Ascorbate peroxidase-a hydrogen peroxide scavenging enzyme in plants. Plant Physiology., 85: 235-241.

7. Asada, K. (1994): Production and action of active oxygen species in photosynthetic tissues. In: Foyer CH, M Mullineaux P (eds) Causes of Photooxidative stress and amelioration of defense systems in plants. CRC Press, Boca Raton, Florida, United States America, pp. 77-104.

8. AzevedoNeto , A. D. , Prisco, J. T., Enéas-Filho, J., De Abreu, C. E. B. and Gomes-Filho, E. (2006):Effect of salt stress on antioxidative enzymes and lipid peroxidation in leaves and roots of salt-tolerant and salt-sensitive maize genotypes. Environmental and Experimental Botany.,56: 87- 94.

9. Bandoniene, D., Murkovic, M., Pfannhauser, W., Venskutonis, P. R., and Gruzdiene, D. (2002):Detection and activity evaluation of radical scavenging compounds by using DPPH free radical and on-line HPLC-DPPH methods. European Food Research Technology.,214: 143-147.

10. Bashandy, T., Guilleminot, J., Vernoux, T., Caparros-Ruiz, D., Ljung, K., Meyer, Y. and Reichheld, J.P. (2010): Interplay between the NADP-linked thioredoxin and glutathione systems in Arabidopsisauxin signaling. Plant Cell., 22: 376-391.

11. Baumann, H. A., Morrison, L. and Stengel, D. B. (2009): Metal accumulation and toxicity measured by PAM - Chlorophyll fluorescence in seven species of marine macroalgae. Ecotoxicology and Environmental Safety.,72 (4): 1063-1075.

12. Beauchamp, C.H. and Fridovixh, I. (1971):Superoxide dismutase: improved assays and an assay applicable to acrylamide gels. Analytical Biochemistry., 44: 276- 287.

13. Benavides, M.P., Gallego, S.M. and Tomaro, M.L. (2005): Cadmium toxicity in plants. Brazilian Journal of Plant Physiology., 17:21-34.

14. Blokhina, O., Virolainen, E. and Fagerstedt, K.V. (2003): Antioxidants, oxidative damage and oxygen deprivation stress: a review. Annals of Botany., 91: 179-194.

15. Bouhlal, R., Haslin, C., Chermann, J.C., Colliec-Jouault, S., Sinquin, C., Simon, G., Cerantola, S., Riadi, H. and Bourgougnon, N. (2011): Antiviral activities of sulfated polysaccharides isolated from Sphaerococcuscoronopifolius (Rhodophytha, Gigartinales) and Boergeseniellathuyoides (Rhodophyta, Ceramiales). Marine Drugs., 9:1187-1209.

16. Carfagna, S., Lanza, N., Salbitani, G., Basile, A., Sorbo, S. and Vona, V. (2013): Physiological and morphological responses of Lead or Cadmium exposed Chlorella sorokiniana 211-8K (Chlorophyceae). Springer Plus., 2: 147.

17. Caverzan, A., Casassola, A. and Brammer, S.P. (2016): Reactive oxygen species and antioxidant enzymes involved in plant tolerance to stress. . In: Shanker A, Shanker C (eds) Abiotic and biotic stress in plants. recent advances and future perspectives Tech, DOI: 10.5772/61368, pp. 463-480.

18. Chen, C. and. Dickman, M.B. (2005): Proline suppresses apoptosis in the fungal pathogen Colletotrichumtrifolii. Proceeding of the National Academy of Sciences of the United States of America., 102: 3459-3464.

19. Chen, J.P., Hong, L., Wu, S.N. and Wang, L. (2002): Elucidation of interactions between metal ions and caalginate based on ion exchange resin by spectroscopic analysis and modeling simulation. Langmuir., 18 (24): 9413-9421.

20. Cobbett, C.S. (2000): Phytochelatins and their roles in heavy metal detoxification. Plant Physiology., 123: 825832.

21. Collén, J., Pinto, E., Pedersên, M. and Colepicolo, P. (2003): Induction of oxidative stress in the red macroalga Gracilariatenuistipitataby pollutant metals. Archives of Environmental Contamination and Toxicology., 45: 337-342.

22. Contreras-Porcia, L., Dennett, G., González ,A., Vergara, E., Medina, C., Correa, J.A. and Moenne, A. (2011): Identification of copper-induced genes in the marine alga Ulva compressa (Chlorophyta). Marine Biotechnology.,13(3): 544-56.

23. DeForest, D.K., Brix, K.V. and Adams, W.J. (2007): Assessing metal bioaccumulation in aquatic environments: the inverse relationship between bioaccumulation factors, trophic transfer factors and exposure concentration. Aquatic Toxicology., 84: 236-246.

24. De Oliveira e Silva AM, Vidal Novoa A, Batista-González AE, Pinto JR, Portari Mancini DA, et al. (2012): Antioxidant activity and hepatoprotectivie properties of polyphenols in vitro and in vivo from seaweeds Halimeda opuntia (Linnaeus) Lamouroux. Redox Rep., 17(2): 47-53. 
25. Del Rìo, L. A., Sandalio, L. M., Corpas, F. J., Palma, J. M. and Barroso, J. B. (2006): Reactive oxygen species and reactive nitrogen species in peroxisomes. Production, scavenging, and role in cell signaling. Plant Physiology., 141(2): 330-335.

26. Delmail, D., Labrousse, P., Hourdin, P., Larcher, L., Moesch, C. and Botineau, M. (2011): Differential responses of Myriophyllumalterniflorum DC (Haloragaceae) organs to copper: physiological and developmental approaches. Hydrobiologia., 664(1): 95-105.

27. Devi, G.K., Maniyannan, K., Thirumaran, G., Rajathi, F.A.A. and Anantharaman, P. (2011): In vitro antioxidant activities of selected seaweeds from Southeast coast of India. Asian Pacific Journal of Tropical Medicine.,4: 205-211.

28. Devi, S.R. and Prasad, M.N.V. (1998): Copper toxicity in Ceratophyllum demersum L. (Coontail), a freefloating macrophyte: response of antioxidant enzymes and antioxidants. Plant Science.,138: 157-165.

29. Dietz, K.J. and Pfannschmidt, T. (2011):Novel regulators in photosynthetic redox control of plant metabolism and gene expression. Plant Physiology., 155: 1477-1485.

30. Dourado, M. N., Souza, L. A., Martins, P. F., Peters, L. P., Piotto, F. A., and Azevedo, R. A. (2014): Burkholderia sp. SCMS54 triggers a global stress defense in tomato enhancing cadmium tolerance. Water, Air, and Soil Pollution., 225: 1-16.

31. Elbaz, A., Wei, Y.Y., Meng, Q., Zheng, Q. and Yang, Z.M. (2010): Mercury-induced oxidative stress and impact on antioxidant enzymes in Chlamydomonas reinhardtii. Ecotoxicology., 19: 1285-1293.

32. Figueiredo, F., Encarnação, T. and Campos, M.G.( 2016): Algae as functional foods for the elderly. Food and Nutrition Sciences., 7: 1122-1148.

33. Flores-Garnica J.G., Morales-Barrera, L., Pineda-Camacho, G. and Cristiani-Urbina, E. (2013):Biosorption of $\mathrm{Ni}(\mathrm{II})$ from aqueous solutions by Litchi chinensis seeds. Bioresource Technology., 136: 635-643.

34. Foyer, C. H., Trebst, A. and Noctor, G. (2006): Protective and signalling functions of ascorbate, glutathione and tocopherol in chloroplasts. In: Demmig-Adams B, Adams WWand Mattoo AK (eds) Advances in photosynthesis and respiration. Photoprotection, Photoinhibition, Gene Regulation, and Environment. Dordrecht, the Netherlands, Kluwer Academic Publishers. 21, pp. 241-268.

35. Foyer, C.H. and Halliwell, B. (1976): The presence of glutathione and glutathione reductase in chloroplasts: a proposed role in ascorbic acid metabolism. Planta., 133: 21-25.

36. Foyer, C.H. and Noctor, G. (2005):Oxidant and antioxidant signaling in plants: a reevaluation of the concept of oxidative stress in a physiological context. Plant, Cell and Environment., 28:1056-1071.

37. Foyer, C.H. and Noctor, G. (2011):Ascorbate and glutathione: the heart of the redox hub. Plant Physiology.,155: 2-18.

38. Ganesan, P., Kumar, C.S. and Bhaskar, N. (2008): Antioxidant properties of methanol extract and its solvent fractions obtained from selected Indian red seaweeds. Bioresource Technology.,99: 2717-2723.

39. Gill, S.S. and Tuteja, N. (2010):Reactive oxygen species and antioxidant machinery in abiotic stress tolerance in crop plants. Plant Physiology and Biochemistry. , 48: 909-930.

40. Gratão, P.L., Polle, A., Lea, P.J. and Azevedo, R.A. (2005): Making the life of heavy metal-stressed plants a little easier. Functional Plant Biology., 32: 481-494.

41. Han, T., Kang, S.H., Park, J.S., Lee, H.K. and Brown, M.T. (2008): Physiological responses of Ulva pertusa and U. armoricana to copper exposure. Aquatic Toxicology., 86(2): 176- 184.

42. Hare, P.D. and Cress, W.A. (1997): Metabolic implications of stress-induced proline accumulation in plants. Plant Growth Regulation., 21: 79-102.

43. Hartree, E. F. (1972): Determination of protein: a modification of the lowry method that gives a linear photometric response. Analytical Biochemistry., 48(2): 422- 427.

44. Heath, R. and Packer, L. (1968):Photoperoxidation in isolated chloroplasts. Kinetics and stoichiometry of fatty acid peroxidation. Archives of Biochemistry and Biophysics., 125:189-198.

45. Hissin, P. J. and Hilf, R. (1976):A fluorimetric method for determination of oxidized and reduced glutathione in tissues. Analytical Biochemistry., 74:214-226.

46. Hope, A.B. and Walker, N.A. (1975):The Physiology of Giant Algal Cells, Cambridge University. Press, Cambridge, UK, pp.1975.

47. Hou J., Wu Y., Li X., Wei B., Li S., Wang X. (2018): Toxic effects of different types of zinc oxide nanoparticles on algae, plants, invertebrates, vertebrates and microorganisms. Chemosphere., 193: 852-860.

48. Hu, J., Shi, G., Xu, Q., Wang, X., Yuan, Q and Du, K. (2007): Effect of $\mathrm{Pb}^{2+}$ on the active oxygen scavenging enzyme activities and ultrastructure in Potamogeton crispus leaves. Russian Journal of Plant Physiology., 54(3):414-419. 
49. Hurd, C.L. Harrison, P.J., Bischof, K. and Lobban, C.S. (2014): Seaweed Ecology and Physiology (2 ${ }^{\text {nd }}$ eds), Cambridge University Press, pp.387-389.

50. Imlay, J.A. and Linn, S. (1988): DNA damage and oxygen radical toxicity. Science., 240:1302-1309.

51. Irigoyen, J. J., Emerich, D. W. and Sanchezdiaz, M. (1992):Water stress induced changes in concentrations of proline and total soluble sugars in nodulated alfalfa (Medicago sativa) plants. Plant Physiology.,84, (1): 55- 60.

52. Israr, M., Sahi, S., Datta, R. and Sarkar, D. (2006): Bioaccumulation and physiological effects of mercury in Sesbania drummondii. Chemosphere., 65: 591-598.

53. Jiang, H.P., Gao, B.B., Li, W.H., Zhu, M., Zheng, C.F., Zheng, Q.S. and Wang, C.H. ( 2013): Physiological and biochemical responses of Ulva prolifera and Ulva linza to cadmium Stress. The Scientific World., 2013: 1-11.

54. Jiménez, A., Hernández, J.A., del Río, L.A. and Sevilla, F. (1997): Evidence for thepresence of the ascorbateglutathion cycle in mitochondria and peroxisomes of pea (Pisum sativum L.) leaves. Plant Physiology., 114: 275-284.

55. Joseph, E.A., Radhakrishnan, V.V. and Mohanan, K.V. (2015): A Study on the accumulation of proline - an osmoprotectant amino acid under salt stress in some native rice cultivars of North Kerala, India. Universal Journal of Agricultural Research., 3(1):15-22.

56. Kelman, D., Posner, E.K., McDermid, K.J., Tabandera, N.K., Wright, P.R. and Wright, A.D. (2012): Antioxidant activity of Hawaiian marine algae. Marine Drugs., 10 (2): 403-416.

57. Kuda, T., Tsunekawa, M., Goto, H. and Araki ,Y. (2005): Antioxidant properties of four edible algae harvested in the Noto Peninsula, Japan. Food Composition and Analysis., 18: 625-633.

58. Kumar, M., Kumari, P., Gupta, V., Anisha, P. A., Reddy, C. R. K. and Jha, B. (2010): Differential responses to cadmium induced oxidative stress in marine macroalga Ulva lactuca (Ulvales, Chlorophyta). Biometals., 23: 315-325.

59. Larson, R.A. (1988): The antioxidants of higher plants. Phytochemistry., 27(4): 969-978.

60. Lee M.Y. and Shin, H.W. (2003): Cadmium-induced changes in antioxidant enzymes from marine alga Nannochloropsis oculata. Applied Phycology., 15:13- 19.

61. Liang, X., Zhang, L., Natarajan, S.K. and Becker, D.F. (2013):Proline mechanisms of stress survival. Antioxidants and Redox Signaling., 19(9): 998-1011.

62. Lobo, V., Patil, A., Phatak, A. and Chandra, N. (2010): Free radicals, antioxidants and functional foods: Impact on human health. Pharmacognosy Reviews., 4(8): 118-126.

63. Mallick, N. (2004): Copper-induced oxidative stress in the chlorophycean microalga Chlorella vulgaris: response of the antioxidant system. Plant Physiology., 161: 591-597.

64. Mallick, N. and Mohn, F.H. (2000): Reactive oxygen species: response of algal cells. Plant Physiology. , 157: 183-93.

65. Mamboya, F.A., Lyimo, T.J. and Björk, M. (2007): Long-term and seasonal variations of heavy metal concentrations in a brown macroalga, the case of Padina gymnospora in the Zan-zibar Channel (Submitted). Stockholm University library., pp.1-48.

66. Matysik, J., Bhalu A.B. and Mohanty, P. (2002): Molecular mechanisms of quenching of reactive oxygen species by proline under stress in plants. Current Science., 82: 525-532.

67. Miao A.J., Wang W.X. and Juneau P. (2005): Comparison of $\mathrm{Cd}, \mathrm{Cu}$, and $\mathrm{Zn}$ toxic effects on four marine phytoplankton by pulse amplitude- modulated fluorometry. Environmental Toxicology and Chemistry., 24(1): 2603-2611.

68. Moucheshi, A.S., Shekoofa, A. and Pessarakli, M. (2014): Reactive oxygen species (ROS) generation and detoxifying in plants. Journal of plant nutrition., 37: 1573-1585.

69. Murugan, K. and Iyer, V.V. (2012): Antioxidant and Antiproliferative Activities of Marine Algae, Gracilaria edulis and Enteromorpha lingulata, from Chennai Coast. International Journal of Cancer Research., 8: 15-26.

70. Nakano, Y. and Asada, K. (1981): Hydrogen peroxide is scavenged by ascorbate-specific peroxidase in spinach chloroplasts. Plant and Cell Physiology., 22(5): 867-880.

71. Narula, P., Mahajan, A., Gurnani, C., Kumar, V. and Mukhija, S. (2015):Microalgae as an indispensable tool against heavy metals toxicity to plants: A review. International Journal of Pharmaceutical Sciences Review and Research., 31(1): 86-93.

72. Nguyen-Deroche, T.L.N., Caruso, A., Le, T.T., Bui, T.V., Schoefs, B., Tremblin, G. and Morant-Manceau, A. (2012): Zinc affects differently growth, photosynthesis, antioxidant enzyme activities and phytochelatin synthase expression of four marine diatoms. Scientific World., 2012(2), Article ID: 982957: 1-15.

73. Panda, S. K., Choudhury, S. and Patra H. K. (2016): Heavy-Metal-induced oxidative stress in plants: Physiological and molecular perspectives. In: Tuteja N, Gill SS (1st ed) Abiotic stress response in plants, Wiley-VCH Verlag GmbH and Co. KGaA, Weinheim, Germany, pp. 219-231 
74. Park, H., McGinn, P.J. and Morel, F.M.M. (2008): Expression of cadmium carbonic anhydrase of diatoms in seawater. Aquatic Microbial Ecology.,5: 183-193.

75. Raskin, I., Kumar, P.B.A.N., Dushenkov, S. and Salt, D. (1994): Bioconcentration of heavy metals by plants. Current Opinion Biotechnology., 28: 115-26.

76. Ratkevicius, N., Correa, J.A. and Moenne, A. (2003): Copper accumulation, synthesis of ascorbate and activation of ascorbate peroxidase in Enteromorpha compressa (L.) Grev. (Chlorophyta) from heavy metalenriched environments in northern Chile. Plant and Cell Environment.,26: 1599-1608.

77. Rausch, T. (1981): Estimation of micro-algal protein content and its meaning to the evaluation of algal biomass. Comparison of methods for extracting protein. Hydrobiologia.,78: 237-251.

78. Romero-Puertas, M.C., Corpas, F.J., Rodriguez-Serrano, M., Gomez, M., Del-Rio, L.A. and Sandalio, L.M. (2007): Differential expression and regulation of antioxidative enzymes by cadmium in pea plants. Plant Physiology., 164:1346-1357.

79. Ryu, B.M., Qian, Z.J., Kim, M.M., Nam, K.W. and Kim, S.K. (2009): Anti-photoaging activity and inhibition of matrix metalloproteinase (MMP) by marine red alga, Corallina pilulifera methanol extract. Radiation Physics and Chemistry., 78:98- 105.

80. Sandalio, L., Dalurzo, H.C., Gomez, M., Romero-Puertas, M. and Del-Rio, L.A. (2001): Cadmium induced changes in the growth and oxidative metabolism of pea plants. Experimental Botany., 52: 215-2126.

81. Santoso, J., Yoshie-Stark, Y. and Suzuki, T.( 2004): Antioxidant activity of methanol extracts from Indonesian seaweeds in an oil emulsion model. Fisheries Science., 70: 183-188.

82. Sbihi K., Cherifi O., El gharmali A., OudraB. and Aziz F. (2012):Accumulation andtoxicological effects of cadmium, copper andzinc on the growth and photosynthesis of thefreshwater diatom Planothidiumlanceolatum (Brébisson) Lange-Bertalot: A laboratory study. Materials and Environmental Science., 3(1): 497-506.

83. Seth, C.S., Remans, T., Keunen, E., Jozefczak, M., Gielen, H., Opdenakker, K., Weyens, N., Vangronsveld, J. and Cuypers, A. (2012): Phytoextraction of toxic metals: A central role for glutathione. Plant, Cell and Environment., 35: 334-346.

84. Shao, H.B., Chu, L.Y., Lu, Z.H. and Kang, C.M. (2007): Primary antioxidant free radical scavenging and redox signaling pathways in higher plant cells. International Journal of Biological Sciences.,4: 8-14.

85. Sharma, S. and Dietz, K.J. (2009):The relationship between metal toxicity and cellular redox imbalance. Trends in Plant Science., 14: 43-50.

86. Signorelli, S., Coitiño, E. L., Borsani, O., and Monza, J. (2014): Molecular mechanisms for the reaction between ${ }^{\circ} \mathrm{OH}$ radicals and proline: Insights on the role as reactive oxygen species scavenger in plant stress. Physical Chemistry B., 118 (1):37-47.

87. Smeets, K., Cuypers, A., Lambrechts, A., Semane, B., Hoet, P., Laere, A. V. and Vangronsveld, J. (2005): Induction of oxidativestress and antioxidative mechanisms in Phaseolus vulgaris after Cd application. Plant Physiology and Biochemistry., 43: 437-444.

88. Smeets, K., Opdenakker, K., Remans, T., Van Sanden, S., Van Belleghem, F., Semane, B.,Horemans, N., Guisez, Y., Vangronsveld, J. and Cuypers, A. (2009): Oxidativestress related responses at transcriptional and enzymatic levels after exposure to $\mathrm{Cd}$ or $\mathrm{Cu}$ in a multi pollution context. Plant Physiology., 166: 1982-1992.

89. Smirnoff, N. (1996): The function and metabolism of ascorbic acid in plants. Annals of Botany., 78: 661-669.

90. Smirnoff, N., and Cumbes, Q.J. (1989): Hydroxyl radical scavenging activity of compatible solutes. Phytochemistry., 28:1057-1060.

91. Srivalli, B., Chinnusamy, V. and Khanna-Chopra, R. (2003): Antioxidant defense in response to abiotic stresses in plants. Plant Biology., 30: 121-139.

92. Stanley, M.S., Perry, R.M. and Callow, J.A. (2005): Analysis of expressed sequence tags from the green algal Ulva linza (Chlorophyta). Phycology., 41: 1219-1226.

93. Sunda, W.G. (1989): Trace metal interactions with marine phytoplankton. Biological Oceanography., 6:411442 .

94. Takami, R., Almeida, J.V., Vardaris, C.V., Colepicolo, P. and Barros, M.P.( 2012): The interplay between thiol-compounds against chromium (VI) in the freshwater green alga Monoraphidium convolutum: Toxicology, photosynthesis, and oxidative stress at a glance. Aquatic Toxicology., 118-119: 80-87.

95. Tchounwou, P.B., Yedjou, C.G., Patlolla, A.K. and Sutton, D.J. (2014): Heavy metals toxicity and the environment. In: Luch A (eds) Molecular, clinical and environmental toxicology. Experientia Supplementum, 101, pp.133-164.

96. Valko, M., Morris, H. and Cronin, M.T.D. (2005): Metals, toxicity and oxidative stress. Current Medicinal Chemistry., 12: 1161-1208. 
97. Wang, J. Zhang, H. and Allen, R. D. (1999):Over expression of an Arabidopsis peroxisomal ascorbate peroxidase gene in tobacco increases protection against oxidative stress. Plant and Cell Physiology., 40(7): $725-732$.

98. Wang, Z., Zhang, Y., Huang, Z. and Huang, L. (2008): Antioxidative response of metal accumulator and nonaccumulator plants under cadmium stress. Plant Soil., 310: 137-149.

99. Williams, L. and Salt, D. E. (2009): The plant ionome coming into focus. Current Opinion in Plant Biology., 12: 247-249.

100.Wu, T.M., Hsu, Y.T, Sung, M.S., Hsu, Y.T. and Lee, T.M. (2009):Expression of genes involved in redox homeostasis and antioxidant defense in a marine macroalga Ulva fasciata by excess copper. Aquatic Toxicology., 94: 275-285.

101.Xia, J. R., Li, Y. J., Lu, J. and Chen, B. (2004): Effects of Copper and Cadmium on Growth, Photosyntesis, and Pigment Content in Gracilaria Lemaneiformis. Bulletin of Environmental Contamination and Toxicology., 73( 6): 979-986.

102. Yadav, S.K. (2010): Heavy metals toxicity in plants: an overview on the role of glutathione and phytochelatins in heavy metal stress tolerance of plants. South African Journal of Botany.,76: 167-179. 